\title{
DIFFERENT BOOSTING SYSTEMS AND THEIR CONTROL STRATEGIES FOR A SPARK IGNITION INTERNAL COMBUSTION ENGINE
}

\section{ONDŘEJ BOLEHOVSKÝ, JAN MACEK}

Czech Technical University in Prague, Faculty of Mechanical Engineering, Technická 4, 16607 Prague 6, Czech Republic

E-mail: ondrej.bolehovsky@fs.cvut.cz, jan.macek@fs.cvut.cz

\section{SHRNUTí}

Tato práce využivá 1-D simulací (GT-Power) k porovnání různých přeplňovacích systémů pro zážehový motor. Výfukovými plyny hnané turbodmychadlo a mechanicky hnaný kompresor (typu Roots) jsou v ustálených a přechodových režimech hodnoceny z hlediska účinnosti, spotřeby paliva, jízdní dynamiky a dalších aspektů, které ovlivňují výměnu náplně válce. Výzkum se zaměřuje také na různé prístupy v řizení těchto přeplňovacích systémů, zvláště v nízkých zatí̌eních. Výsledky práce poslouží k nalezení optimálního přeplňovacího systému pro standardizované nebo reálné jízdní cykly.

KLIČCOVÁ SLOVA: DOWNSIZING, DOWNSPEEDING, PŘEPLŇOVACÍ SYSTÉMY, TURBODMYCHADLO, ROOTSŮV KOMPRESOR, ŘíZENÍ WASTE-GATE, ZMĚNA ZATíŽENÍ, ZÁŽEHOVÝ MOTOR, SPOJKA KOMPRESORU, 1-D SIMULACE

\section{ABSTRACT}

This research uses 1-D simulation in GT-Power for evaluation of boosting systems for a spark ignition engine. Exhaust gas driven (waste-gated turbocharger) and mechanical driven (Roots blower) boosting systems are assessed in both steady state and transient modes in terms of performance, efficiency, fuel consumption, drivability, energy distribution and other aspects that influence gas exchange phase. Moreover, different boost control strategies, particularly at partial load, are also evaluated. Results of the research are aimed at helping identify an optimal boosting system for standardized or real-world drive cycles.

KEYWORDS: DOWNSIZING, DOWNSPEEDING, BOOSTING SYSTEMS, TURBOCHARGER, ROOTS SUPERCHARGER, WASTE-GATE CONTROL, LOAD CHANGE, SPARK IGNITION ENGINE, SUPERCHARGER CLUTCH, 1-D SIMULATION

\section{INTRODUCTION}

Efforts to improve the fuel economy of vehicles with internal combustion engines (ICE) over the drive cycle has led to downsizing and downspeeding, which are terms linked to an increase in ICE brake efficiency. Downsizing represents the reduction of displacement of the engine. To retain the required performance, a proper boosting device, ensuring higher intake pressure, must be added to the ICE ([5], [6], [7], [8], [10], [12]). Downspeeding is referred to as the reduction of engine speed (RPM), which in turn further reduces friction losses of the engine and allows the engine to run at higher load at the same power output ([4], [5], [11], [12], [14]). Again this can be enabled by a suitable boosting device which allows sufficient boost pressure to be supplied at low engine speed.

The boosting system represents a new device or devices coupled with the engine, and its features also influence the engine itself. This is why there are certain demands placed on the boosting system. It should feature low power demand, fast pressure build-up during transients, a wide range of operation with high isentropic efficiency, lightweight and easy packaging, fast warmup of after-treatment systems and their control, minimum NVH issues and cost ([4], [6], [7], [8]).

The two most common types of boosting systems in contemporary ICEs are: an exhaust gas driven turbocharger, consisting of two vane machines (centripetal turbine and centrifugal compressor, [10], [11], [13]), or positive displacement pumps that are driven mechanically by the crankshaft ([3], [4], [7], [9]). The well-known commercial products of such type are, e.g., Roots supercharger produced by Eaton, or Lysholm supercharger produced by Lysholm Technologies. There are also new emerging technologies utilizing electrically driven devices, which might be either positive displacement or vane machines ([8], [11]). The aim of the paper is to compare the exhaust gas driven turbocharger and the mechanically driven Roots blower at steady state and semi-transient operation, both at full load and partial load mode, with different control strategies, and to evaluate their benefits and drawbacks. 


\section{SIMULATION SET-UP AND INITIAL ENERGY BALANCE ANALYSIS}

A light duty 4-cylinder spark ignition (gasoline) engine model with $1.4 \mathrm{dm}^{3}$ displacement was selected for assessment purposes. Rated power was set to $90 \mathrm{~kW}$ at $5000 \mathrm{rpm}$ and torque 200 $\mathrm{Nm}$ at $1500-4000 \mathrm{rpm}$. The turbocharged layout (with wastegate for intake pressure control) was chosen as the baseline, and supercharged models were derived from it by replacing the turbocharger. In the case of the Roots supercharger, there were several sizes and series evaluated on the engine model and the most suitable sizes from each series were selected for the final assessment. Boost pressure of the Roots blowers was controlled by bypassing the supercharger. All layouts were equipped with the charge air cooler. Valve lift profiles and valve timing were not optimized, and no change was made to the AF ratio map for the gasoline engine (lower values for the supercharged layout due to no turbine temp. protection). Roots blower (supercharger) performance maps were provided by Eaton [3].

The basic difference between the turbocharger and Roots blower (supercharger) boosted engine is for simplicity presented by means of energy balance of a simulated 2.0L Diesel engine (with the same conditions for both layouts) in Figures 1 and 2 respectively. The turbocharger utilizes a part of the exhaust gas energy (area encompassed by the red dashed line) as a drive which covers most of the power required from the centrifugal compressor. The Roots blower does not utilize waste exhaust gas energy; the energy for the drive is taken from the effective work of the engine, but some power can be recovered through pumping work, which is positive, and the resulting indicated work is higher (upper curve of the effective work field compared to the dashed curve in Figure 2). However, after subtracting the power input of the supercharger (red dashed line area in

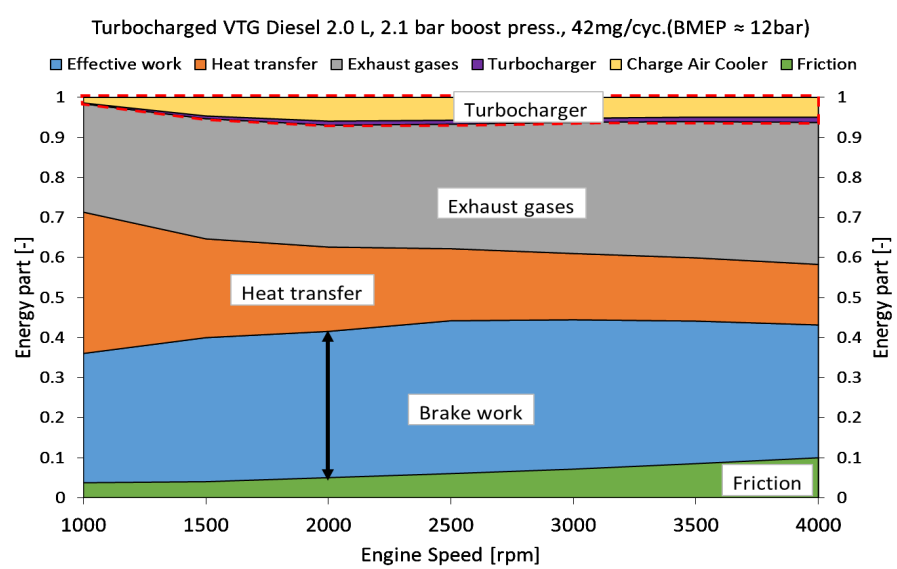

FIGURE 1: Energy distribution: Turbocharged VTG Diesel 2.0 L, 2.1 bar boost press., $42 \mathrm{mg} / \mathrm{cyc}$. (BMEP $\approx 12 \mathrm{bar}$ )

OBRÁZEK 1: Toky energií: Turbodmychadlem přeplňovaný vznětový motor, 2,0I, plnicí tlak 2,1 bar, dávka 42 mg/cyklus
Figure 2) the resulting effective work is usually lower than for the turbocharged engine layout. The increasing heat transfer fraction with decreasing engine speed is remarkable and can work against the downspeeding benefit. A significant amount of energy is also lost in the charge air cooler. The rest of the power input for the boosting system, which was not transferred to the charge air cooler, increases the enthalpy of the air at the engine intake, which is consequently added to the enthalpy released during combustion (i.e., transferred to the effective work).

\section{STEADY STATE CONDITIONS}

\subsection{FULL LOAD}

The baseline turbocharged layout performance for the gasoline engine at full load is presented in Figure 3 in the form of brake mean effective pressure (BMEP). The maximum torque curve is kept flat starting at $1500 \mathrm{rpm}$ and then decreasing after 4000 rpm due to the limitations of the turbocharger.

As a mechanically driven boost device, two Roots blower series were studied, the $R$ and $V$ series, which are commercial product family names used by Eaton. The R series with rotors of fourlobe design and high twist angle, reaching peak efficiency island at a high supercharger speed, and the V series with rotors of three-lobe design and lower twist angle reaching peak efficiency island at lower supercharger speeds. Two unit sizes from each series were preselected as most suitable for such an engine, namely R410 and V400. The number in the name stands for the volume (in $\mathrm{cm}^{3}$ ) transferred in one revolution of the supercharger. Matching the supercharger to the engine using a proper gear ratio is an important task. For better understanding, the gear ratio is stated in the opposite way to that usually used, i.e., $G R=n_{\text {supercharger }} / n_{\text {crankshaft }}$ In this research the supercharger was in one case permanently coupled to the crankshaft with either constant gear ratio over the full engine speed range, or with

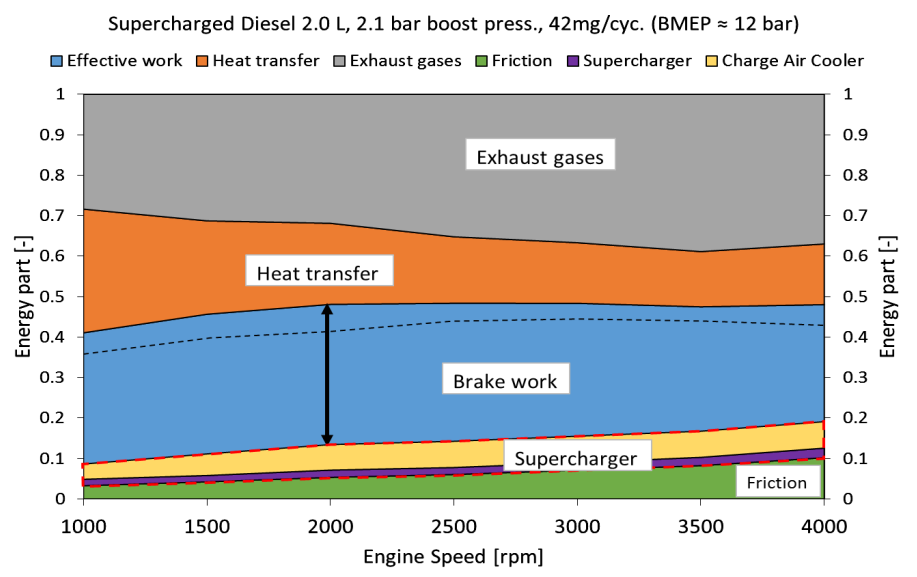

FIGURE 2: Energy distribution: Supercharged Diesel 2.0 L, 2.1 bar boost press., $42 \mathrm{mg} / \mathrm{cyc}$. (BMEP $\approx 12 \mathrm{bar}$ )

OBRÁZEK 2: Toky energií: Mech. kompresorem přeplňovaný vznětový motor, 2,0 I, plnicí tlak 2,1 bar, dávka 42 mg/cyklus 


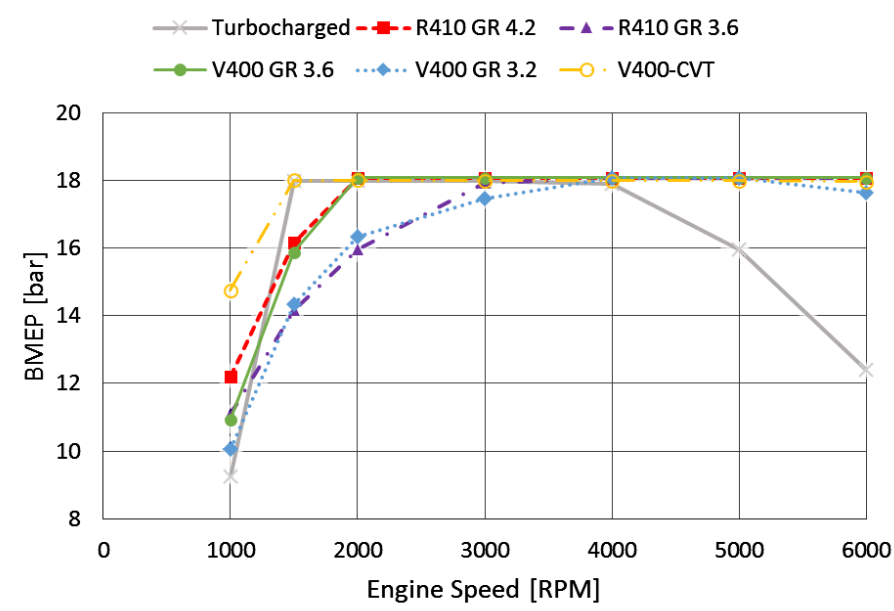

FIGURE 3: 1.4 gasoline engine; BMEP - Turbocharger vs. Roots Supercharger; Full Load

OBRÁZEK 3: Zážehový motor 1,4l; BMEP - Turbodmychadlo vs. Rootsův kompresor; plné zatížení

a variable transmission, and in the other case it was coupled to the crankshaft by a dry friction clutch, which could be disengaged at low loads. The issue of supercharger engagement by a clutch will be discussed in the next chapter.

In the effort to achieve the performance of the turbocharged engine layout (Figure 3), a higher GR had to be selected, which in turn requires earlier bypassing at lower engine speed with even higher bypassing at high engine speed. This leads to higher power consumption of the supercharger (due to the higher mass flow rate and elevated air temperatures at its inlet) and worse fuel consumption of the engine. The $V$ series supercharger achieved such performance with significantly lower gear ratio (3.6) compared to the $R$ series (4.2) due to the different rotor design and the position of peak isentropic efficiency in the supercharger map. Since the well-known advantage of the supercharger is almost immediate response in transients, it is possible to sacrifice maximum low-end torque and decrease the gear ratio to minimize the bypassing penalty. This variant is also depicted in Figure 3 , with gear ratio 3.2 for the $V$ series and 3.6 for the $R$ series. Also of note is the ability of the superchargers to provide sufficient boost pressure over a wide engine speed range, so that BMEP can be kept high even at high engine speed.

Figure 4 shows the corresponding brake specific fuel consumption (BSFC) for all layouts. It is clear that all supercharger layouts have worse BSFC than the turbocharged layout. The influence of lower gear ratio for superchargers is quite significant; at lower engine speed it reaches the values of the turbocharged layout, which is also caused by the lower engine torque related to better indicated efficiency at this engine speed due to the optimal ignition timing and higher lambda value (knocking avoidance and protection of components in the exhaust manifold).

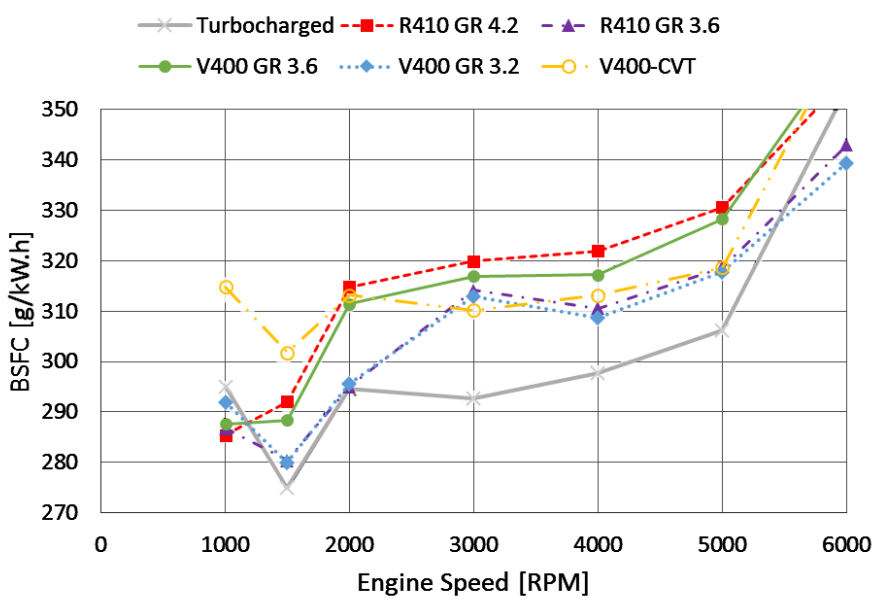

FIGURE 4: 1.4 gasoline engine; BSFC - Turbocharger vs. Roots Supercharger; Full Load

OBRÁZEK 4: Zážehový motor 1,4 I; BSFC - Turbodmychadlo vs. Rootsův kompresor; plné zatížení

The use of a continuous variable transmission ("CVT") coupling the supercharger and engine crankshaft would be very beneficial, as it continuously changes the gear ratio in order to match otherwise different characteristics of the engine and the supercharger, and the need for disadvantageous bypassing is removed or minimized. Lower boost pressure required at lower engine load would also be controlled just by changing the gear ratio without the necessity for bypassing. Such a study was carried out for the V400 supercharger and the result is plotted in Figures 3 and 4 ("CVT"). Mechanical losses in such a transmission were neglected for this simulation. The required gear ratio ranged from approx. 6 at low engine speed with decreasing tendency to 3.2 at higher engine speed. Bypassing was necessary only at very low engine speed where the flow rate through the supercharger was increased in this manner in order to keep the operating point in the map of the supercharger (avoiding conditions adverse for the supercharger). In this case the BMEP curve is superior to the turbocharged one.

\subsection{PARTIAL LOAD}

As increased intake pressure is only demanded for higher loads, which is not very often under real driving conditions, it is obviously advantageous to minimize the influence of the boosting device, particularly as it gives rise to engine losses.

In the case of turbocharger boosting, there are two opposing control strategies at light loads - the first strategy leaves the waste-gate closed, so that there is a slightly higher pressure upstream of the throttle valve and also upstream of the turbine, which results in faster transient response. However, this is at the expense of slightly worse fuel economy due to higher pumping work. The second strategy bypasses the turbine via the wastegate so that there is almost no backpressure upstream of the 


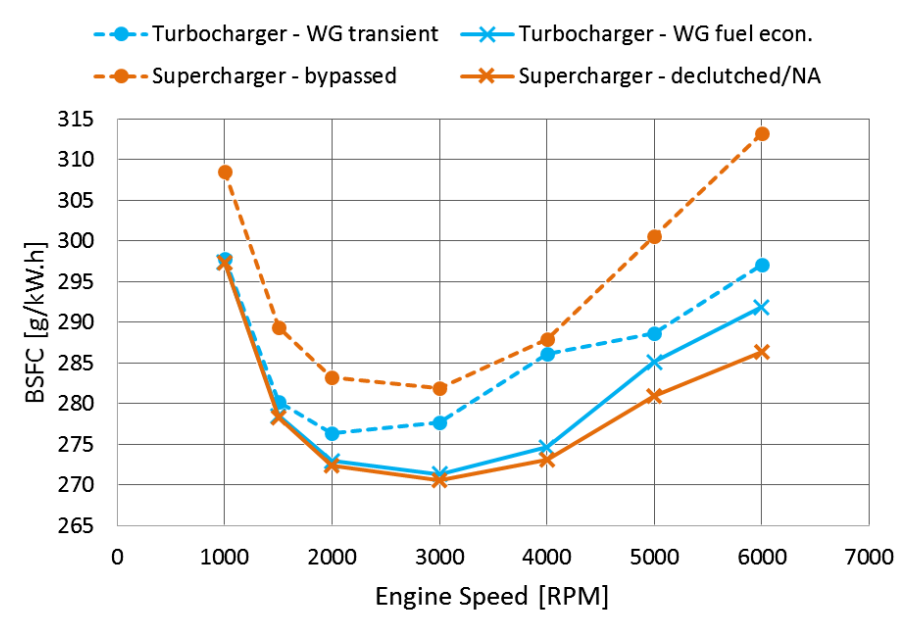

FIGURE 5: 1.4 gasoline engine; BMEP = 5 bar; Turbocharger vs. Roots Supercharger (different boost control)

OBRÁZEK 5: Zážehový motor 1,4l; BMEP = 5 bar; Turbodmychadlo vs. Rootsův kompresor (různé řízení)

turbine, but when there is an immediate demand for high torque, there is a greater delay in turbocharger/engine response. Car manufacturers usually prefer the first strategy in order to minimize the well-known turbo-lag.

For the Roots blower boosting system, there is a bypass valve which is fully opened and the supercharger works at a pressure ratio close to 1 , so there is little supercharger power consumption. However, the Roots blower and the whole drive system also exhibits mechanical friction losses as well as a moment of inertia (reduced by the square of the supercharger -> crankshaft gear ratio). For these reasons the supercharger can be placed downstream of the throttle valve, which makes the supercharger work below atmospheric pressure conditions and thus its power consumption is lower. Another approach is just to connect the supercharger to the engine temporarily using a dry friction clutch that is, e.g., electromagnetically controlled. This means that the supercharger is engaged only when the regime approached the wide-open throttle position. At light loads the bypassing route is used with the opposite flow direction to bypass the supercharger, and the engine thus runs as a naturally aspirated one.

All the above strategies for boost control (of both turbocharger and supercharger) are compared in Figure 5 at low load (BMEP $=5$ bar) at steady state. An interesting conclusion from this is that in the case of the turbocharged layout with the transient oriented control strategy, the brake specific fuel consumption (BSFC) is about 5 grams higher than for the supercharged layout with the disengaged supercharger (i.e., naturally aspirated engine). Keeping the supercharger connected and bypassed causes losses which are reflected in worse BSFC than the transient oriented control strategy for the turbocharger layout.

\section{TRANSIENT CONDITIONS}

Due to the fact that real driving conditions are often far from the steady state mode, it is important to also evaluate the behavior of these boosting devices in the transient modes. Manufactures work on the basis of standardized drive cycles, which are not fully representative of real driving conditions either. The planned WLTP cycle is more transient than the old European NEDC, and better approximates real driving conditions.

For this purpose, a simple elementary semi-transient process at the level of an engine itself was carried out, i.e., engine speed is kept constant and a load change (step) is introduced (similar to engine dyno testing). The subsequent response of each specific engine layout (different boosting system) is then observed and analyzed. For this purpose an improved control strategy for the boosting systems was developed to ensure that the bypass or turbine waste-gate closes fast enough in order to minimize the influence on the boosting device response. Another torque control system was the main throttle valve. The moment of inertia of the turbocharger was adjusted according to available similar tests on the real engine.

In order to understand the load step processes from the performance (drivability) and energy balance point of view, a load change from 2 to 16 bar of BMEP at $1500 \mathrm{rpm}$ is presented in Figure 6 . The required load change (step) is plotted as a green line, the response of the turbocharged layout is shown by the continuous dark grey curve (TC-load) and supercharger layout (V400) response is the continuous red curve (SC_upstr._THR-load). Typical lag of the turbocharger response can be seen in Figure 6, with a short steep ramp at the beginning (also common for a supercharger) followed by slow build-up of engine torque due to spinning up of the turbocharger with a certain moment of inertia. In the case of the permanently connected supercharger, the initial ramp is continuous with the same slope and reaches $90 \%$ of the required load within a second.

The arrangement with the supercharger placed downstream of the main throttle valve (described above) has a slightly slower response (SC_downstr._THR-load in Figure 6), because the bigger manifold volume, which is under sub-atmospheric conditions at partial load, needs more time to be filled with the pressurized air. In the case of the disengaged supercharger (e. g., clutch connection), it is obvious to position the supercharger upstream of the throttle valve to minimize the throttled volume and reduce response in transients.

To assess the energy balance during the load step at constant engine speed, a special variable called BSFCcum. is introduced. It calculates the cumulative work performed since the beginning of the step (kW.h), divided by cumulative fuel consumption (in grams) since the beginning of the load step: 


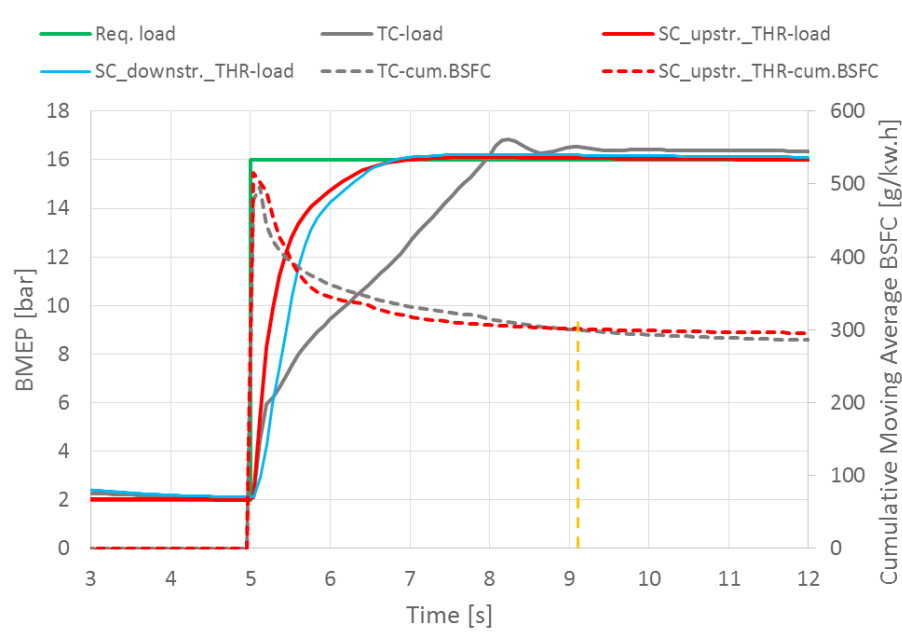

FIGURE 6: 1.4 Gasoline Engine - Load Step Response at 1500 RPM (Step 2 -> 16 bar)

OBRÁZEK 6: Zážehový motor 1,4I - odezva na skokovou změnu zatížení ( 2 -> 16 bar) v $15001 / \mathrm{min}$.

$B S F C_{\text {cum. }}=\frac{\int_{T 1}^{T} \dot{m}_{f} \cdot d t}{\int_{T 1}^{T} T \cdot \omega_{\text {eng }} \cdot d t .3600}$

where $B S F C_{\text {cum }}$ is the cumulative moving average of $B S F C$ $[\mathrm{g} / \mathrm{kW} . \mathrm{h}], \dot{m} f$ is the fuel mass flow rate $[\mathrm{kg} / \mathrm{s}], T$ is the instantaneous brake torque $[\mathrm{Nm}], \omega_{\text {eng. }}$ is the angular velocity of the engine $[\mathrm{rad} / \mathrm{s}]$.

This is clearer when looking at an overtaking maneuver, in this case with a CVT transmission to maintain constant engine speed. During this maneuver the vehicle/engine must do some work and it can take either more time (with lower average power) or less time (higher average power). Since the engine in the second case runs faster at higher load, i.e., at higher brake efficiency, the overtaking maneuver can be performed with better fuel consumption even with an engine which has worse fuel economy at steady state (but better transient response). The proof of this statement can be seen in Figure 6 with dashed curves (colors corresponding to the load curves of each layout) representing the above-mentioned cumulative BSFC which determines the point up to which (after the load step start) a certain engine is superior to the other layout. In this case, the supercharged engine ceases to be beneficial as late as 4 seconds after the load step start (marked with vertical dashed yellow line), which is a remarkable finding.

The same test as shown in Figure 6 was also performed for a load step at partial load, i.e., in the throttled region, from 2 to 5.5 bar of BMEP, as shown in Figure 7. Since there is no bypass on the side of the centrifugal compressor (turbocharger), demand for higher mass flow through the main throttle valve is required also for the centrifugal compressor and a slight delay

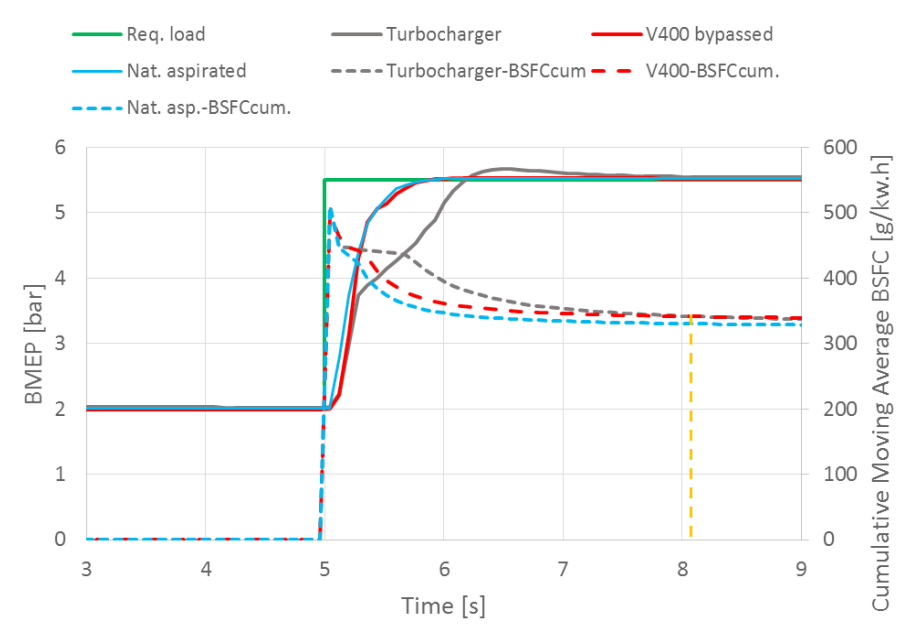

FIGURE 7: 1.4 Gasoline Engine - Load Step Response at 1500 RPM (Step 2 -> 5.5 bar)

OBRÁZEK 7: Zážehový motor 1,4I - odezva na skokovou změnu zatížení (2 -> 5,5 bar) v $15001 / \mathrm{min}$.

(lag) is noticeable. In this step the turbocharger waste-gate was initially fully opened and it closes right at the load step start. Due to this effect, the supercharger layout - marked red (bypassed, but engaged) - again shows better fuel economy in the 3 seconds after the load step. The naturally aspirated engine (or declutched supercharger) is marked in blue for comparison. The other approach with the initially closed turbocharger wastegate (transient oriented) would give a response time comparable to supercharger layouts.

\section{SUPERCHARGER WITH DRY CLUTCH CONNECTION}

Engagement of the supercharger to the engine crankshaft with a clutch represents an important and difficult issue, because we need to equalize non-zero engine speed with zero supercharger speed and bring the supercharger (of a given moment of inertia) up to a speed of $20000 \mathrm{rpm}$ or more. Such acceleration means high instantaneous power input, which must be covered by the engine according to equation 2 .

$P_{\text {eng,inst. }}=I_{S C} \cdot \frac{d \omega_{S C}}{d t} \cdot \frac{1}{G R} \cdot \omega_{\text {eng }}$

where $P_{\text {eng, inst. }}$ is the instantaneous power input $[\mathrm{W}], I_{S C}$ is the moment of inertia of the supercharger rotors $\left[\mathrm{kg} \cdot \mathrm{m}^{2}\right], \omega_{S C}$ is the angular velocity of the supercharger $[\mathrm{rad} / \mathrm{s}], G R$ is the gear ratio between the crankshaft and supercharger rotor [-].

In addition, there is the thermodynamic power consumption itself, which should be established soon after or at the end of the engagement and which must also be accounted for. This puts 
high demands on the engaging control. The main parameters that influence the supercharger engagement process are:

- Timing of start of the clutch engagement (what is the farthest point in the naturally aspirated mode where the supercharger engagement can start)

- Duration of engagement = clutch slip (depends on sufficient surplus of indicated torque to overcome peak torque occurring at the crankshaft)

- Timing and rate of bypass valve closing (usually starts at the end of the engagement process)

For this purpose a dry clutch engagement system was built in the GT-Power model of the above mentioned supercharged gasoline engine equipped with the V400 Roots blower (placed upstream of the throttle valve). The clutch model was adjusted according to the expected torque requirement of the supercharger (i.e., minimum static clutch torque, effective radius, actuator force variation during engagement), and the friction properties were taken from GT-Power library. The design itself, thermal and mechanical durability of the clutch connection have not been pursued in this work. Supercharger moment of inertia was obtained from Eaton.

A control algorithm was constructed in order to properly control both clutch system and bypass system. The crucial parameters for control of the clutch engagement and bypass were optimized in a simulation test where a load change (step) from various partial loads to full load at constant engine speed was evaluated. The goal was to find a combination of parameters that would reengage the supercharger as fast as possible without any lagging in brake torque. If there is not enough spare indicated torque to cover the engagement process (too close to the maximum naturally aspirated torque curve), or if this process including bypass closing is too fast, brake torque drops at the beginning and the driver would experience a hesitation similar to turbo-lag.

Figure 8 presents an optimum case for lower engine speed, where the engagement process is smooth and no decrease in brake torque occurs. After the demand for higher engine load, the clutch is connected and the clutch torque immediately exceeds the maximum static torque of the clutch, which is in slip mode at that time. This enables smooth spin-up of the supercharger and limits the torque transmitted to the crankshaft (expressed in Figure 8 by means of mean effective pressure - "Aux. MEP"), so that the available indicated torque (without friction mean eff. pressure) is not depleted during the engagement. The dark grey dashed curve shows the bypass valve diameter, which goes to zero when the supercharger is at its target speed. For comparison there is also the BMEP response of the permanently engaged supercharger (thin dashed red curve in Figure 8). It shows that there is a small delay in the order of magnitude of a few tens of milliseconds for the clutch layout.

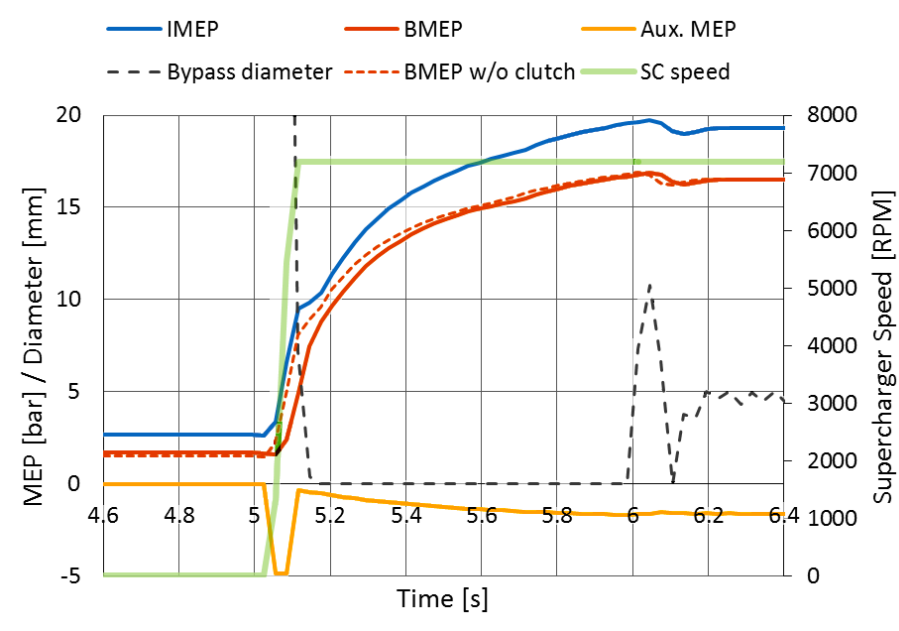

FIGURE 8: Supercharger Engagement Process: Load Step 2 -> 16 bar at $5^{\text {th }}$ second at 2000 RPM

OBRÁZEK 8: Průběh připojování mech. kompresoru - skok. změna 2->16 bar v 2000 1/min.

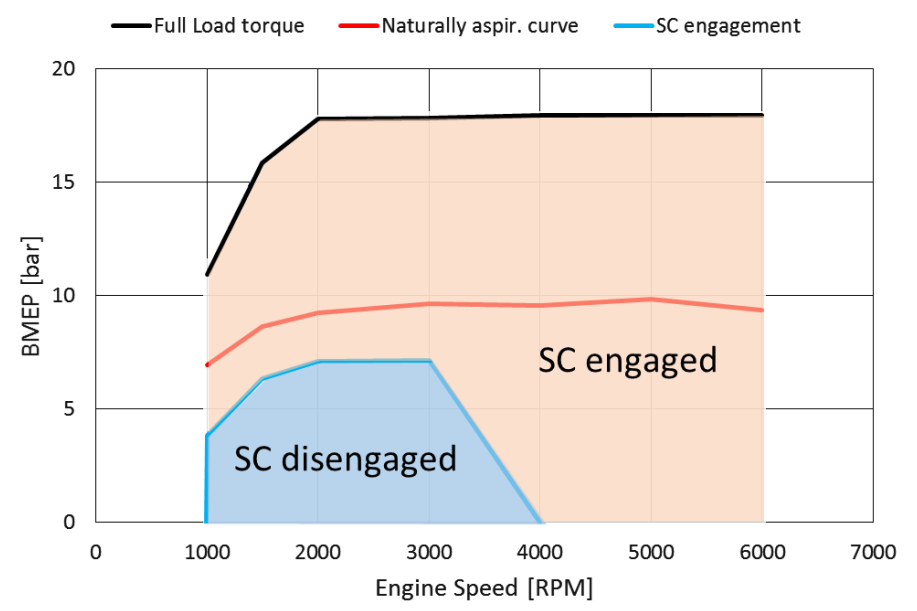

FIGURE 9: Supercharger Disengagement Operation Area OBRÁZEK 9: Provozní oblast motoru s odpojeným kompresorem

The optimization shows that there are only some operation points in which it is possible to engage the supercharger sufficiently fast without a lag in brake torque. The area of supercharger disconnection is shown in Figure 9 (in BMEP vs. Eng. speed coordinates) and its upper border is determined by the spare torque (remaining below the naturally aspirated torque curve) that must be utilized for reengagement, and the skew border on the right hand side is constrained by a too-high speed to which the supercharger would have to be spun-up. In this blue area it is possible to connect the supercharger to the engine during a reasonable time scale (approximately $0.3 \mathrm{sec}$.) without any drop in the brake torque. This operation area corresponds to engine loads which are mostly utilized driving in real urban conditions, and this disconnection of the supercharger brings some benefit in fuel economy (see Figure 9); however, testing in driving cycles in a future work must be done to quantify this. 


\section{CONCLUSION}

The work assessed behavior of the spark ignition engine with single boosting systems of different design. The exhaust gas driven turbocharger is a well-established boosting system for current engines and the results proved that it provides fuel consumption benefits mainly at steady state modes. However, the dependency of the turbocharger on the enthalpy of exhaust gases also brings a disadvantage, notably under transient conditions, where it lacks fast response, mainly at low engine speed, which sacrifices vehicle drivability when engine downspeeding is applied.

The simulation further highlights that mechanically driven positive displacement pumps (Roots blower in this work) suffer from an inability to utilize the energy of exhaust gases, which results in worse fuel economy at steady state conditions. However, independence from exhaust gas energy can be seen as an advantage when it comes to transients, where it provides a fast response. It was also proved that the fast response of a boosting system (employing a Roots blower in this case) during a load step allows the engine to work faster at higher brake efficiency, and it can bring some fuel economy benefit despite the fact that steady state BSFC numbers are worse than for the turbocharged engine. It is important to mention that the valve lift profile and timing was not optimized for simulated layouts (default settings transferred from turbocharged layouts) and there might be higher potential in the derived models with supercharger.

The boosting devices were also evaluated at partial engine load with different boost control strategies. The results also show a certain difference at partial load, where the turbocharger layout with transient oriented waste-gate control has higher fuel consumption at steady state than the declutched supercharger (corresponding to the naturally aspirated engine). Further, the issue of disconnection via a dry clutch of the Roots blower was solved in detail by means of simulation. Optimization has shown that there is only a small area in the engine operation range where it is possible to sufficiently fast connect the supercharger to the engine; however, this area corresponds to the operation points which are usually used during a real urban driving cycle. Further work will focus on variable valve actuation and its application and evaluation in drive cycles.

\section{ACKNOWLEDGEMENT}

This work has been realized using support of:

- Technology Agency of the Czech Republic, Competence Centres programme, project \# TE01020020 Josef Božek Competence Centre for Automotive Industry.

- The Ministry of Education, Youth and Sports program NPU I (LO), project \# L01311 Development of Vehicle Centre of Sustainable Mobility.

- Eaton European Innovation Centre within the Student Research Services Agreement.

This support is gratefully acknowledged.

\section{LIST OF ABBREVIATIONS}

$\begin{array}{ll}\text { BMEP } & \text { Brake Mean Effective Pressure [bar] } \\ \text { RPM } & \text { Revolution Per Minute } \\ \text { GR } & \text { Gear Ratio } \\ \text { BSFC } & \text { Brake Specific Fuel Consumption } \\ \text { CVT } & \text { Continuous Variable Transmission } \\ \text { WG } & \text { Waste-gate } \\ \text { NEDC } & \text { New European Driving Cycle } \\ \text { WLTC } & \text { Worldwide harmonized Light duty vehicle Test Cycle } \\ \text { TC } & \text { Turbocharger } \\ \text { SC } & \text { Supercharger } \\ \text { BSFC }_{\text {cum. }} & \text { Cumulative moving average of Brake Specific } \\ & \text { Fuel Consumption } \\ \mathrm{P}_{\text {eng. inst. }} & \text { Instantaneous brake power of the engine }\end{array}$

\section{REFERENCES}

[1] GAMMA TECHNOLOGIES, INC. Flow Theory Manual, 2012

[2] Macek, J., Spalovací turbiny, turbodmychadla a ventilátory, Praha, ČVUT v Praze, 2006, ISBN 80-01-03529-8

[3] Eaton Corp. 2013. Supercharger performance maps data. Unpublished internal document

[4] Froehlich, M., Stewart, N.: "TVS V-Series Supercharger Development for Single and Compound Boosted Engines", SAE Technical Paper 2013-01-0919, 2013, doi: 10.4271/2013-01-0919

[5] Keidel, S., Wetzel, P., Biller, B., Bevan, K. et al., "Diesel Engine Fuel Economy Improvement Enabled by Supercharging and Downspeeding", SAE Technical Paper 2012-01-1941, 2012

[6] Pohorelsky, L., Brynych, P., Macek, J., Vallaude, P. et al., "Air System Conception for a Downsized Two-Stroke Diesel Engine", SAE Technical Paper 2012-01-0831, 2012, doi: 10.4271/2012-01-0831

[7] Eiser, A., Fitzen, M., Heiduk, T., Mendle, J., Zahlmann, S., Baumel, F., "3.0 TFSI The New Top-of-the-Range V6-Engine from Audi", MTZ Online, Vol. 70, 09/2009, p. 10-18 
[8] Ricardo, M. B., Apostolos, P., Yang, M. Y., "Overview of boosting options for future downsized engines.", Sci China Tech Sci, 2011, doi: 10.1007/s11431-010-4272-1

[9] Navratil, J., Polasek, M., Vitek, O., Macek, J., Baumruk, P.: "Simulation of Supercharged and Turbocharged Small Spark-Ignition Engine", MECCA, Volume I., Number 3, 2003, Praha

[10] Bauer, K., Balis, C., Donkin, G., Davies, P.:

"The Next Generation of Gasoline Turbo Technology", 33. Internationales Wiener Motorensymposium 2012

[11] Cieslar, D.: "Control for Transient Response of Turbocharged Engines", Ph.D. Thesis, Department of Engineering, University of Cambridge, March 2013

[12] Ostrowski, G., Neely, G., Chadwell, C., Mehta, D. et al., "Downspeeding and Supercharging a Diesel Passenger Car for Increased Fuel Economy," SAE Technical Paper 2012-01-0704, 2012, doi: 10.4271/2012-01-0704

[13] Petitjean, D., Bernardini, L., Middlemass, C., and Shahed, S., "Advanced Gasoline Engine Turbocharging Technology for Fuel Economy Improvements," SAE Technical Paper 2004-01-0988, 2004, doi:10.4271/2004-01-0988

[14] McBroom, S., Smithson, R., Urista, R. and Chadwell, C., "Effects of Variable Speed Supercharging Using a Continuously Variable Planetary on Fuel Economy and Low Speed Torque," SAE Int. J. Engines 5(4): 2012, doi: 10.4271/2012-01-1737 